\section{Detection of the Downy Mildew Pathogen on Seed of Basil Following Field Infection in Southern New Jersey}

\author{
Christian A. Wyenandt ${ }^{1,6,12}$, Lisa R. Maimone ${ }^{2,7}$, \\ Kathryn Homa ${ }^{2,8}$, Angela M. Madeiras ${ }^{3,9}$, Robert L. Wick ${ }^{4,10}$, \\ and James E. Simon ${ }^{5,11}$
}

AdDitional INDEx wORDs. real-time PCR, Peronospora belbabrii, O. americanum, O. basilicum, O. citriodorum, O. tenuiflorum

Summary. Different basils (Ocimum sp.) and cultivars (28 in 2009 and 32 in 2010) were evaluated for susceptibility to basil downy mildew (Peronospora belbabrii) at the Rutgers Agricultural Research and Extension Center near Bridgeton in southern New Jersey. At the end of each growing season, seed was collected from individual plants and stored for potential downy mildew pathogen detection using real-time polymerase chain reaction (PCR) analysis. Most of the basil cultivars and breeding lines were showing symptoms of basil downy mildew infection at the time of seed collection before the first frost near the end of the production season. Symptoms of basil downy mildew were present on 25 of the $28(89 \%)$ basil lines evaluated in 2009 and 26 of $32(81 \%)$ basil lines tested in 2010 at the time of seed harvest, with sporulation evident on the abaxial surface of infected leaves. Real-time PCR analysis of seed collected from various infected plants detected P. belbabrii on seed of 14 of $25(56 \%)$ basil lines tested in 2009 and 8 of $32(25 \%)$ tested in 2010. Importantly, P. belbahrii was not only detected on seed of sweet basil (Ocimum basilicum) phenotypes but also on seed of 'Spice' basil (Ocimum americanum) in 2009 and 'Sweet Dani Lemon Basil' basil (Ocimum citviodorum), 'Holy Red and Green' basil [Ocimum tenuiflorum (form. sanctum)], 'Lime' basil (O. americanum), and again on 'Spice' basil in 2010 where no symptoms (i.e., no chlorosis or sporulation) were present on the leaves when seed were collected. This work demonstrates that basil seed, regardless of basil species and whether symptoms are visible on foliage of the basil plant or the plant is immune or resistant to downy mildew, can test positive for the presence of $P$. belbabrii using a real-time PCR assay following exposure of plants to the pathogen during the natural development of downy mildew under field conditions.

S weet basil is the most commercially important, annual, culinary herb crop grown in the United States (Wyenandt et al., 2010). Culinary basil is grown for both fresh and dry consumption. Basil is a source of essential oil and oleoresin for manufacturing perfumes, food flavors, and aromatherapy products (Simon et al., 1990). Basil downy mildew, caused by Peronospora belbahrii, is an economically important disease of basil species in the United States (Roberts et al., 2009; Wyenandt et al., 2015). Downy mildew has been reported in many countries and several continents (Belbahri et al., 2005; Garibaldi et al., 2004a, 2005; Hansford, 1933; Khateri et al., 2007; McLeod et al., 2006; Ronco et al., 2008). In the United States, the pathogen was first discovered in Fall 2007 in Florida (Roberts et al., 2009). Since then, basil downy mildew has been found throughout most of the United States, including all major production areas $(\mathrm{McGrath}$ et al., 2010; Wick and Brazee, 2009; Wyenandt et al., 2015). The symptoms of basil downy mildew on an infected plant can resemble a nutrient deficiency (Fig. 1). Like other downy mildew pathogens, $P$. belbabrii will only produce sporangia on the abaxial surface of infected leaves. Numerous dark, purplish-brown sporangia are produced when environmental conditions are favorable for disease development
(Fig. 2). Periods of high humidity, warm temperatures, poor air circulation, and extended durations of leaf wetness are favorable for $P$. belbabrii and can result in extensive development of basil downy mildew throughout plantings (Cohen et al., 2017; Garibaldi et al., 2005, 2007; McGrath et al., 2010; Spencer, 1981). In northern areas, such as the mid-Atlantic and northeast regions of the United States, there is no evidence that this obligate pathogen can survive outdoors during winter months between field-grown basil crops. However, oospore production in basil leaves has been reported in Israel (Cohen et al., 2013). The pathogen has been shown to survive on contaminated seed (Garibaldi et al., $2004 b$ ). Since 2010 , the epidemiology of basil downy mildew has been studied extensively (Cohen et al., 2017). However, making accurate predictions about its development and dissemination across broad geographic regions remains problematic. In 2009, 49 visual reports of basil downy mildew were logged from 17 U.S. states and Canada (McGrath et al., 2010). These reports confirmed the first major basil downy mildew outbreak in the eastern U.S. and helped establish that, under ideal weather conditions, basil downy mildew can disseminate over a wide geographic region in a single growing season across the United States (McGrath et al., 2010 ). Since 2009 , basil downy mildew has been reported in 42 U.S. states, including Hawaii and Alaska (Wyenandt et al., 2015). Since its arrival, $100 \%$ losses have occurred on many farms in New Jersey and across the mid-Atlantic and northeast regions as well as the rest of the United States. Once basil plants become infected and develop symptoms on leaves, they are no longer marketable as a fresh product (Fig. l).

It has been widely suggested that the rapid and widespread distribution of basil downy mildew in recent years has been attributed to the distribution

\begin{tabular}{llll}
\hline $\begin{array}{l}\text { Units } \\
\begin{array}{l}\text { To convert U.S. to SI, } \\
\text { multiply by }\end{array}\end{array}$ & U.S. unit & SI unit & $\begin{array}{l}\text { To convert SI to U.S., } \\
\text { multiply by }\end{array}$ \\
\hline 29,574 & $\mathrm{fl} \mathrm{oz}$ & $\mu \mathrm{L}$ & $3.3814 \times 10-5$ \\
29.5735 & $\mathrm{fl} \mathrm{oz}$ & $\mathrm{mL}$ & 0.0338 \\
0.3048 & $\mathrm{ft}$ & $\mathrm{m}$ & 3.2808 \\
2.54 & inch $(\mathrm{es})$ & $\mathrm{cm}$ & 0.3937 \\
1.1209 & $\mathrm{lb} / \mathrm{acre}$ & $\mathrm{kg} \cdot \mathrm{ha}^{-1}$ & 0.8922 \\
0.0254 & $\mathrm{mil}(\mathrm{s})$ & $\mathrm{mm}$ & 39.3701 \\
28.3495 & $\mathrm{oz}$ & $\mathrm{g}$ & 0.0353 \\
$\left({ }^{\circ} \mathrm{F}-32\right) \div 1.8$ & ${ }^{\circ} \mathrm{F}$ & ${ }^{\circ} \mathrm{C}$ & $\left({ }^{\circ} \mathrm{C} \times 1.8\right)+32$
\end{tabular}


of the pathogen via infested seed (Cohen et al., 2017; Garibaldi et al., 2004b; Wyenandt et al., 2015). In Italy, Garibaldi et al. (2004a) collected sweet basil seed from 17 commercial sources and in greenhouse and growth chamber experiments were able to detect $P$. belbabrii in 4 of 17 plant samples. However, the seed contamination observed in their study appeared to be high enough to allow for rapid spread of the disease. Belbahri et al. (2005) were able to detect $P$. belbabrii using a newly develop PCR technique but were not able to detect the pathogen in or on infected seed. Farahani-Kofoet et al. (2012) were able to detect $P$. belbabrii on artificially infested seed using a PCR assay to the level of a single spore per seed. They also detected $P$. belbabrii in $80 \%$ to $90 \%$ of the commercial seed lots tested and demonstrated that seed collected from infected plants could result in infected plants, with or without symptom development. In Israel, Cohen et al. (2017) could not demonstrate the transmission of $P$. belbabrii in seeds collected from heavily infected plants. Microscopic examination of the seed did not show mycelium or sporangia of the fungus

Funds for this research were provided by U.S. Department of Agriculture (USDA) Special Crops Research Initiative Award No. 2011-51181-30646, the USDA National Institute of Food and Agriculture Award No. 2016-68004-24931, the Binational Agricultural Research and Development (BARD) Award No. US-4947-16R, the New Jersey Agricultural Experiment Station, and the Rutgers Cooperative Extension Service (NIFA HATCH projects NJAES 12131 and 1005685 )

${ }^{1}$ Department of Plant Biology, Rutgers University, Rutgers Agricultural Research and Extension Center, 121 Northville Road, Bridgeton, NJ 08302

${ }^{2}$ Department of Plant Biology, Rutgers University, 59 Dudley Road, New Brunswick, NJ 08901

${ }^{3}$ UMASS Extension, The Center for Agriculture, Food, and the Environment, University of Massachusetts Amherst, Amherst, MA 01003

${ }^{4}$ Stockbridge School of Agriculture, University of Massachusetts Amherst, Amherst, MA 01003

${ }^{5}$ New Use Agriculture and Natural Plant Products Program, Department of Plant Biology, Rutgers University, 59 Dudley Road, New Brunswick, NJ 08901

${ }^{6}$ Extension Specialist in Vegetable Pathology

${ }^{7}$ Undergraduate Student

${ }^{8}$ Graduate Student

${ }^{9}$ Diagnostic Technician

${ }^{10}$ Professor of Plant Pathology and Nematology

${ }^{11}$ Distinguished Professor of Plant Biology and Director

${ }^{12}$ Corresponding author. E-mail: wyenandt@njaes. rutgers.edu.

https://doi.org/10.21273/HORTTECH03849-17 in the embryo (Cohen et al., 2017). However, R.L. Wick and A.M. Madeiras (unpublished data), using seed that tested positive for P. belbahrii by PCR assay, found downy mildew sporangiophores after centrifuging the water that was used to rinse infested basil seed (Fig. 3).

Commercial seed companies currently are seeking to develop seed treatment methods for controlling $P$. belbabrii in basil seed. Currently, there are conventional and organic fungicide options for basil downy mildew control; however, commercial fungicides only work well under low disease pressure and excellent management practices, and no organic options have proven effective (Homa et al., 2014; Wyenandt et al., 2015). Importantly, the lack of genetic resistance to the pathogen in widely grown sweet basil cultivars continues to make control difficult (Homa et al., 2014; Pyne et al., 2015, 2017; Wyenandt et al., 2015). Efforts have been made in recent years at breeding downy mildew resistance into commercially acceptable sweet basil lines (Ben-Naim et al., 2018; Pyne et al., 2015, 2017, 2018), but this has focused on using a few strains of the pathogen and, as with all disease-resistant plants, growers still need to use the improved germplasm within an integrated pest management program that still requires fungicide applications. Should additional strains (e.g., races) of basil downy mildew develop, such as for other downy mildews on other hosts, continued breeding efforts will be required. The development of seed treatment methods and rapid tests to determine the presence of the pathogen on seed also will remain relevant to the global basil industry and stakeholders.

The objective of this study was to determine whether $P$. belbabrii could be detected on seed of different basil cultivars and species from field-grown plants following downy mildew epidemics in southern New Jersey.

\section{Materials and methods}

Collection OF SEED FROM CULTIVARS AND BREEDING LINES. In 2009 and 2010, at Rutgers Agricultural Research and Extension Center near Bridgeton, NJ, different basil species, cultivars, and advanced breeding lines (28 in 2009 and 32 in 2010) were evaluated for susceptibility

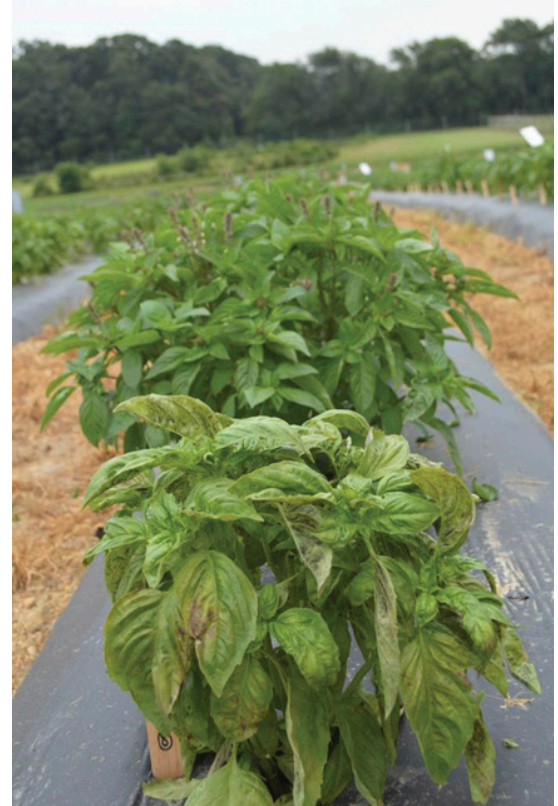

Fig. 1. Downy mildew-infected sweet basil plant in the foreground showing similar symptoms to nutrient deficiency on the top side of leaves and active sporulation of the pathogen on the underside of leaves.

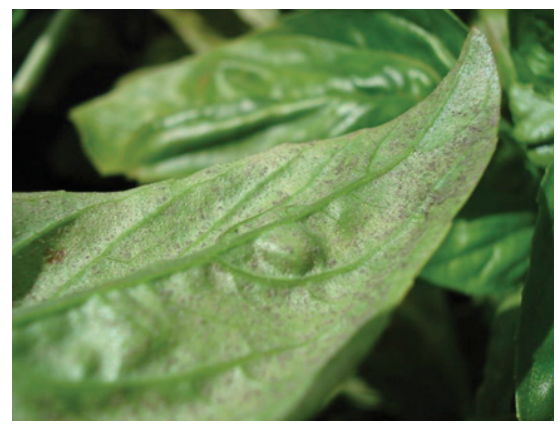

Fig. 2. Basil downy mildew sporulating on the abaxial side of leaves of sweet basil cultivar Superbo.

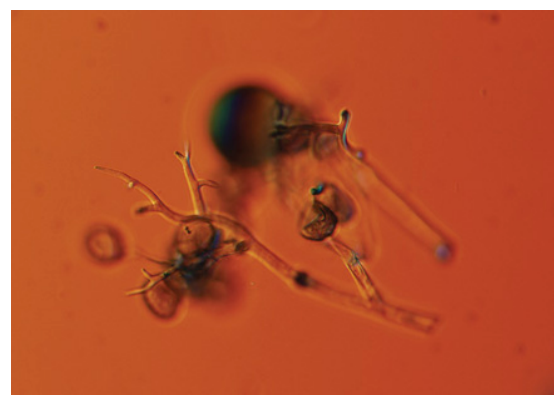

Fig. 3. Sporangiophores and sporangia of the basil downy mildew pathogen recovered from infested sweet basil seed by washing and centrifugation.

to basil downy mildew using a randomized complete block design with four replications in each year (Table 1). 


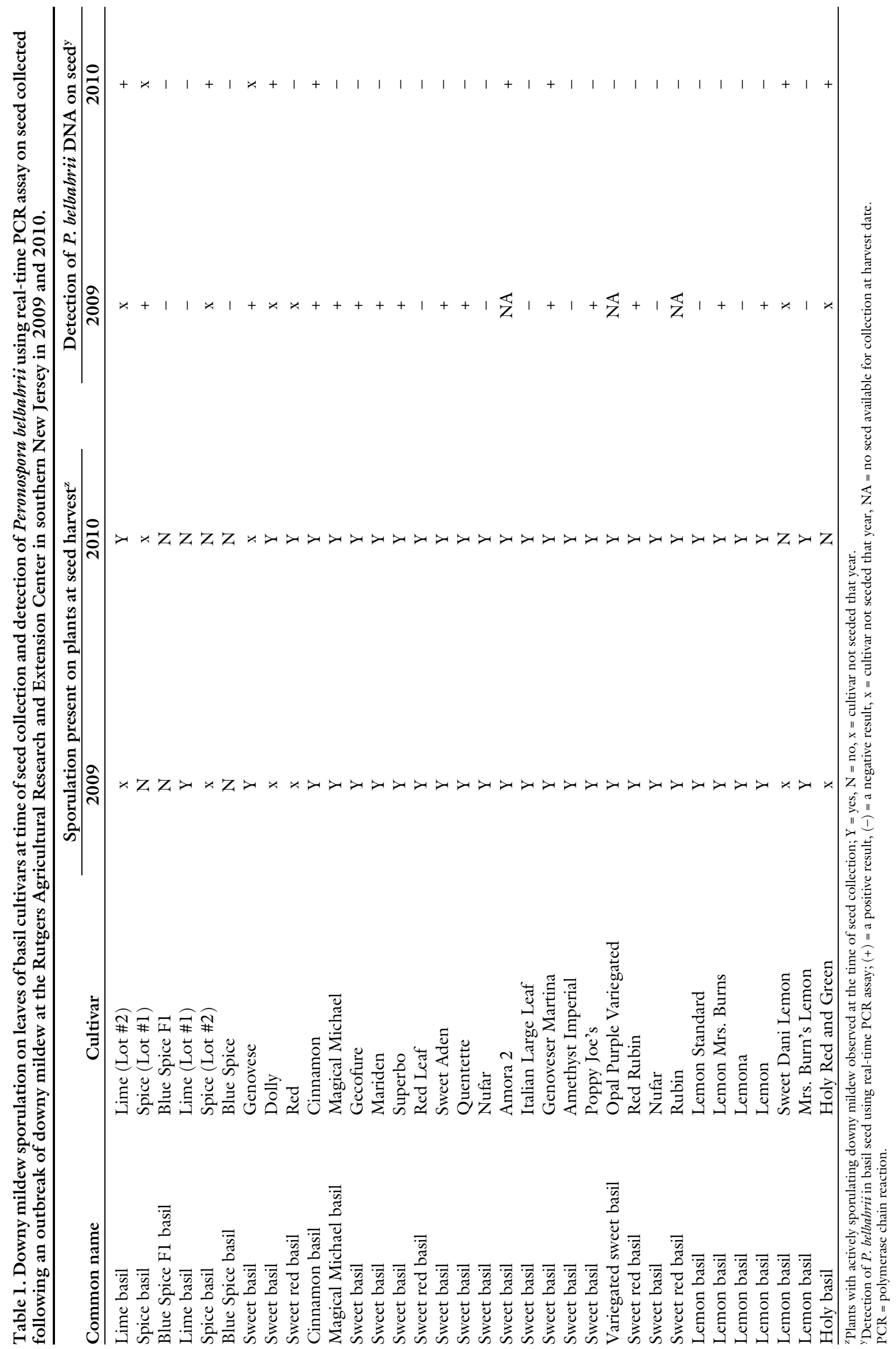

Hortlechnology October 2018 28(5) 
The seed of some cultivars and breeding lines collected in both years of this trial were a part of a larger study that evaluated each for downy mildew susceptibility (Wyenandt et al., 2010). On 27 July 2009 and 22 June 2010, 6week-old basil seedlings were transplanted onto 6-inch-high, raised beds covered with 1.5-mil black plastic mulch and spaced on 5 -ft centers with drip irrigation. All basil plants were transplanted in staggered doublerows. Rows were spaced 16 inches apart, and plants within each row were spaced 9 inches apart. The total number of plants per plot varied, but in general each plot consisted of no less than 20 plants. On 31 July 2009 and 5 Aug. 2010, the field was infested with downy mildew by transplanting 10 infected plants of the sweet basil cultivar Italian Large Leaf randomly throughout the field to promote disease development. Overhead irrigation was applied at regular intervals for up to $4 \mathrm{~h}$ per day to promote disease development. In each year, all plots were drip-irrigated two to three times per week for $\approx 2 \mathrm{~h}$ and fertilized using $2.0 \mathrm{lb} /$ acre of $20 \mathrm{~N}-8.7 \mathrm{P}-16.6 \mathrm{~K}$ (Peters Professional 20-20-20; ScottsSierra Horticultural Products Co., Marysville, $\mathrm{OH}$ ) as needed. On 21 Aug. 2009, all plants were pruned manually to about a 12 - to 18 -inch height depending on growth habit and left to produce seed. Basil plants were not pruned in 2010. In Oct. 2009 and 2010, seed heads from each line were removed from all plants in each plot, with the seed heads from each line kept separated and placed into brown paper bags. Bags containing seed heads were then placed in a dry environment on a greenhouse bench until seeds were extracted. Great care was made to ensure there was no cross contamination at time of seed head collection, to placement of seed into the paper bags, and to the sealing of the paper bags. Seeds were extracted by placing seed heads on a screen and gently grinding to extract most seed from the chaff. The screens were washed and cleaned after and between each sample. All seed were then separated by hand from any remaining chaff and stored at $-80^{\circ} \mathrm{C}$ in small paper envelopes labeled for future use. All seed from each replication of each cultivar or breeding line plot $(n=4)$ was then pooled to form one sample size for testing purposes. In some cases, not enough seed was produced from some cultivars or breeding lines for testing.

DNA EXTRACTION AND REALTIME PCR ANALYSIS OF SEED FOR THE DETECTION OF $P$. BELBAHRII. In 2009, DNA was extracted from seed of 25 of the 28 cultivars. 'Aroma 2', 'Opal Purple Variegated', and 'Rubin' were excluded because of low seed yield. For each cultivar or breeding line, liquid nitrogen was added to a mortar with $\approx 3 \mathrm{~g}$ of seed. The samples were ground to a powder with a pestle. From this, $\approx 0.1 \mathrm{~g}$ of powder was placed in a $0.2-\mathrm{mL}$ minicentrifuge tube and immediately extracted using the DNeasy Plant Mini Kit (QIAGEN, Valencia, CA). The "Mini Protocol" was followed from step 7. Extracted samples were stored at $-80{ }^{\circ} \mathrm{C}$ for further analysis.

DNA extracts were analyzed on the StepOne Real Time PCR System (Applied Biosystems, Foster City, CA). Primers used were designed to detect P. belbabrii: forward: 5' CCG TAT CAA CCC AAT AAT TTG GGG GTT AAT 3'; reverse: 5' TTA CAA TCG TAG CTA CTT GTT CAG ACA AAG 3' (Belbahri et al., $2005)$. Final reaction volume for each well was $20 \mu \mathrm{L}$. Each sample well contained $10 \mu \mathrm{L}$ of Fast SYBR Master Mix (Applied Biosystems CA), $0.9 \mu \mathrm{L}$ each primer, $6.2 \mu \mathrm{L}$ of moleculargrade water, and $2 \mu \mathrm{L}$ of target DNA extract. As a positive control sample, basil leaves with visible $P$. belbahrii were ground in liquid nitrogen and extracted using the QIAGEN protocol as listed previously. Moleculargrade water served as the negative control sample. Real-time PCR assay was run with an initial holding cycle of $95^{\circ} \mathrm{C}$ for $20 \mathrm{~s}$, followed by 40 cycles of $95{ }^{\circ} \mathrm{C}$ for $3 \mathrm{~s}$ for denaturation, $55{ }^{\circ} \mathrm{C}$ for $15 \mathrm{~s}$ for annealing, and $72^{\circ} \mathrm{C}$ for $30 \mathrm{~s}$ for extension. Melt curve analysis was performed. All assays were repeated and run in triplicate.

\section{Results and discussion}

At the time of seed collection, which was before the first frost near the end of the field production season in each year, most of the basil cultivars and breeding lines showed symptoms of basil downy mildew (Table 1). In most cases, downy mildew was actively sporulating on the abaxial side of infected leaves. Symptoms of basil downy mildew were present at seed harvest on 25 of the 28 ( $89 \%$ ) cultivars in 2009 and 26 of 32 (81\%) cultivars in 2010 (Table 1). Infection appears to be the result of $P$. belbabrii spreading naturally from inoculated plants placed in the field. Real-time PCR analysis of seed collected from infected plants determined that DNA of the downy mildew pathogen could be detected on seed of plants showing symptoms of downy mildew or symptomless plants. By using real-time PCR assay, P. belbahrii was detected on seed of 14 of $25(56 \%)$ cultivars tested in 2009 and 8 of $32(25 \%)$ tested in 2010 (Table 1). The differences in the percentage of seed lots testing positive or negative in each year was most likely due to differences in the amount of inoculum present and differences in weather conditions each year. In 2009, the only basil cultivars in which symptoms of downy mildew were not present included Blue Spice, Blue Spice Fl, and Spice (Table 1), each being exotic and non-sweet basil types recognized now to be highly tolerant or immune to basil downy mildew (Ben-Naim et al., 2015; Wyenandt et al., 2010). However, in 2009, P. belbabrii was detected on seed of 'Spice', although no symptoms were present on the plants at the time of seed collection (Table 1 ). In 2010, the only basil cultivars in which symptoms of downy mildew were not present on plants at time of seed collection included Blue Spice Fl, Sweet Dani Lemon Basil, Holy Red and Green, Lime, and Spice. Yet, using a real-time PCR assay, P. belbahrii was still detected on seed of 'Sweet Dani Lemon Basil', 'Holy Red and Green', 'Lime', and 'Spice' (Table 1).

In this study, $P$. belbabrii was detected on or in seed of cultivars for which no symptoms (i.e., no chlorosis or sporulation) were present, indicating that $P$. belbabrii may infest or reside in or on seed of Ocimum species or cultivars that are otherwise considered resistant to the pathogen. It is possible the spores may have contaminated these resistant plants from heavily colonized plants in the field. In some cases, although symptoms were seen on infected plants, the seed tested negative for P. belbabrii. As suggested by Garibaldi et al. (2004b), infested seed could play a significant role in the dissemination of the pathogen across large geographic regions and/or continents. FarahaniKofoet et al. (2012) were able to observe systemic growth as well as 
detect DNA of $P$. belbahrii in stems or leaves of symptomless plants. In contrast, Cohen et al. (2017) were not able to demonstrate seed transmission of $P$. belbahrii in sweet basil. Regardless, the ability of the pathogen to survive in or on seed greatly impacts sweet basil seed production practices, especially if resistant cultivars or species can harbor the pathogen via seed or in planta.

These results suggest that seed of any basil cultivar, including resistant cultivars, should not be produced in the same location where the pathogen has the capability of infecting or infesting susceptible cultivars and vice versa. This is especially important if 1 ) seed testing is not done or unreliable tests or methods are used to detect for the presence of the pathogen; or 2) when seed is to be sold globally or across large geographical areas. Methods for testing and detection of $P$. belbabrii in seed should be adopted by the global basil seed industry to help mitigate dissemination of the pathogen that could lead to widespread outbreaks of the disease. Importantly, there are no industry-accepted, reliable methods for treating basil seed for downy mildew. Producing sweet basil in areas in which the pathogen has not yet been detected may be one strategy to employ, yet the pathogen could still be brought into a farm or region via natural weather patterns or on transplants or potted basils grown in areas where the pathogen is present.

This research demonstrates for the first time that basil seed, regardless of basil species and/or whether the basil plant is susceptible (as in case of commercial sweet basil cultivars) or resistant (as the case of several exotic basils such as 'Spice'), can test positive for the presence of $P$. belbabrii using real-time PCR assay following an outbreak of the disease. Although the presence of the pathogen using the real-time PCR assay does not constitute viability of the inoculum per se, it indicates the importance of quality control practices incorporated into seed increases and collection to avoid the unintentional spread of basil downy mildew on seed.

\section{Literature cited}

Belbahri, L., G. Calmin, F. Lefort, and J. Pawlowski. 2005. Phylogenetic analysis and real time PCR detection of a new
Peronospora species responsible for downy mildew disease of sweet basil and sage. Mycol. Res. 109:1276-1287.

Ben-Naim, Y., L. Falach, and Y. Cohen. 2015. Resistance against basil downy mildew in Ocimum species. Phytopathology 105:778-785.

Ben-Naim, Y., L. Falach, and Y. Cohen. 2018. Transfer of downy mildew resistance from wild basil (Ocimum americanum) to sweet basil (O. basilicum). Phytopathology 108:114-123.

Cohen, Y., Y. Ben Naim, L. Falach, and A.E. Rubin. 2017. Epidemiology of basil downy mildew. Phytopathology 107:1149-1160.

Cohen, Y., M. Vaknin, Y. Ben-Main, A.E. Rubin, M. Galperin, D. Silverman, S. Bitton, and U. Adler. 2013. First report of occurrence and resistance of Peronospora belbabrii, causal agent of basil downy mildew of basil (Ocimum basilicum) in Israel. Plant Dis. 97:692.1.

Farahani-Kofoet, R.D., P. Romer, and R. Grosch. 2012. Systemic spread of downy mildew in basil plants and detection of the pathogen in seed and plant samples. Mycol. Prog. 11:961-966.

Garibaldi, A., A. Minuto, G. Minuto, and M.L. Gullino. 2004a. First report of downy mildew on basil (Ocimum basilicum) in Italy. Plant Dis. 84:1154.

Garibaldi, A., G. Minuto, D. Bertetti, and M.L. Gullino. 2004b. Seed transmission of Peronospora sp. of basil. J. Plant Dis. Prot. 111:465-469.

Garibaldi, A., A. Minuto, and M.L. Gullino. 2005. First report of downy mildew caused by Peronospora sp. on basil (Ocimum basilicum) in France. Plant Dis. 89:683.

Garibaldi, A., D. Bertetti, and M.L. Gullino. 2007. Effect of leaf wetness duration and temperature on infection of downy mildew (Peronospora sp.) basil. J. Plant Dis. Prot. 114:6-8.

Hansford, C.G. 1933. Annual report of the mycologist. Rev. Appl. Mycol. 12:421422.

Homa, K., W.P. Barney, D.L. Ward, C.A. Wyenandt, and J.E. Simon. 2014. Evaluation of fungicides for the control of Peronospora belbabrii on sweet basil in New Jersey. Plant Dis. 89:1561-1566.

Khateri, H., G. Calmin, N. Moarrefzadeh, L. Belbahri, and F. Lefort. 2007. First report of downy mildew caused by $\mathrm{Per}$ onospora sp. on basil in northern Iran. J. Plant Pathol. 89:S70 (abstr.).
McGrath, M.T., C.A. Wyenandt, R.N. Raid, M. Babadoost, and R.L. Wick. 2010 . Occurrence of basil downy mildew in the eastern US in 2009. Phytopathology 100:S196 (abstr.).

McLeod, A., S. Coertze, and L. Mostert. 2006. First report of a Peronospora species on sweet basil in South Africa. Plant Dis. 90:1115.

Pyne, R.M., A.R. Koroch, C.A. Wyenandt, and J.E. Simon. 2015. Inheritance to downy mildew in sweet basil. J. Amer. Soc. Hort. Sci. 140:396-403.

Pyne, R.M., J. Honig, J. Vaiciunas, S. Bonos, A. Wyenandt, and J.E. Simon. 2017. A first genetic map and downy mildew resistance QTL discovery for sweet basil (Ocimum basilicum). PLoS One 12:e184319.

Pyne, R.M., J.A. Honig, J. Vaiciunas, C.A. Wyenandt, and J.E. Simon. 2018. Population structure, genetic diversity and downy mildew resistance among Ocimum species germplasm. BMC Plant Biol. 18:69.

Roberts, P.D., R.N. Raid, P.F. Harmon, S.A. Jordan, and A.J. Palmateer. 2009. First report of downy mildew caused by a Peronospora sp. on basil in Florida and the United States. Plant Dis. 93:199.

Ronco, L., C. Rollán, Y.J. Choi, and H.D. Shin. 2008. Downy mildew of sweet basil (Ocimum basilicum) caused by Peronospora sp. in Argentina. BSPP New Dis. Rpt. 8 Aug. 2018. <http://www.bspp. org.uk/ndr/jan2009/2008-57.asp>.

Simon, J.E., J. Quinn, and R.G. Murray. 1990. Basil: A source of essential oils, p. 484-489. In: J. Janick and J.E. Simon (eds.). Advances in new crops. Timber Press, Portland, OR.

Spencer, D.M. 1981. The downy mildews. Academic Press, London. UK.

Wick, R.L. and N.J. Brazee. 2009. First report of downy mildew caused by a $\mathrm{Per}$ onospora species on sweet basil (Ocimum basilicum) in Massachusetts. Plant Dis. 93:318.

Wyenandt, C.A., J.E. Simon, M.T. McGrath, and D.L. Ward. 2010. Susceptibility of basil cultivars and breeding lines to downy mildew (Peronospora belbabrii). HortScience 45:1416-1419.

Wyenandt, C.A., J.E. Simon, R.M. Pyne, K. Homa, M.T. McGrath, S. Zhang, R.N. Raid, L.J. Ma, R. Wick, L. Gou, and A. Madeiras. 2015. Basil downy mildew (Peronospora belbabrii): Discoveries and challenges relative to its control. Phytopathology 105:885-894. 